\title{
SCIENTIFIC TOY AND NONFORMAL EDUCATION
}

\section{Eva BALÁŽOVÁ}

Abstract: The article deals with a theme of a scientific toy. It explaines a notion, describes goals, balance the activities and achieved results during the existence of a civil association. The article indicates visions and real possibilities of the Scientific Toy in the field of the nonformal education.

Key words: Scientific Toy as a subject, medium of education, interactive exhibitions, competitions with an international participation, nonformal education.

\section{VEDECKÁ HRAČKA A NEFORMÁLNA EDUKÁCIA}

Resumé: Článok sa zaoberá témou vedeckej hračky. Vysvetluje pojem, charakterizuje ciele, bilancuje aktivity a dosiahnuté výsledky počas existencie občianskeho združenia. Naznačuje vízie a reálne možnosti Vedeckej hračky neformálnej edukácii.

Kl'účové slová: Vedecká hračka ako subjekt, prostriedok edukácie, interaktívne výstavy, sútaže s medzinárodnou účastou, neformálna edukácia.

\section{Úvod}

Aktivity Občianskeho združenia Vedecká hračka (d’alej aj ako VH) sú mnohostranné, preto uvádzame tie, ktoré pokladáme za najprínosnejšie $\mathrm{z}$ aspektu neformálnej edukácie. Filozofia Vedeckej hračky vychádza zo skutočnosti, že vo väčšine štátov sveta (nielen v tzv. vyspelých, ale napr. aj v Číne, Chile, Indii, Maroku) pôsobia Centrá vedy, ktoré návštevníkom interaktívnym spôsobom prezentujú rôzne oblasti vedy a techniky. Sú to špecializované zariadenia vybavené spravidla jednoúčelovými exponátmi, ktoré návštevníkom umožňujú vyskúšat' či zažit' prírodné zákony a úkazy vlastným tempom a doslova na vlastnej koži. Viac než 1800 Centier vedy (hand-on-science center, resp. mind-on-science center) je združených v európskej (dostupné na http://www.ecsite.net) a americkej asociácii. Geograficky najbližšie sú Csodák palotája v Budapesti, Techmania v Plzni a IQ Park v Liberci. Podrobnejšie in napr. Balážová, E. - Puobišová, B. (1), Balážová, E. (2). Aká je situácia na Slovensku? Od roku 1991 sa usiluje o konštituovanie podobného zariadenia Nadácia SCHOLA LUDUS, doposial' neúspešne. Občianske združenie Vedecká hračka chce v Banskej Bystrici etablovat' Centrum hier a hračiek, v ktorom budú prostriedkami edukácie hry a hračky.

\section{Vedecká hračka - pojem}

Slovné spojenie Vedecká hračka zaznelo prvýkrát $\mathrm{v}$ podobe „Science Toy“, resp.
„Scientific Toy“ na medzinárodnej prehliadke vedecko-technickej tvorivosti detí a mládeže Expo Science International júli 1991 v Prahe. Vedeckej hračke sa rôznymi formami darí prekonávat' aj umelo a neopodstatnene vytvorenú bariéru, že ,veda nie je hra“ a zároveň spochybňuje neoprávnene zafixovanú predstavu, že „kde začína veda, končí každá hra“. Najmä v ostatnom desat'ročí 20. storočia sa dostal do povedomia detskej i dospelej populácie pojem, ktorý na prvý pohl'ad (alebo počutie) pôsobí kontroverzne. Je to však výstižné označenie a viacvýznamový pojem; vedecká hračka je spoločný menovatel' pre subjekt, prostriedok edukácie, výstavy a sút'aže. Ako jedna z prvých autoriek začala používat' novotvar $\mathrm{v}$ pedagogickej teórii Teplanová, $\mathrm{K}$. (3), neskôr Žbirková, V. - Kratochvílová, E. a kol. (4). Postupne sa táto kategória zaužívala v slovenskej i v českej odbornej terminológii, napr. Kubániová, E. (5); Korim, V. (6); Roučová, E. (7) a i.

\section{Vedecká hračka - subjekt}

Vedecká hračka je dobrovol'né záujmové nepolitické mládežnícke občianske združenie, pôsobiace v Slovenskej republike. Občianske združenie (d’alej aj OZ) založili účastníci vyhodnotenia sút'aže SCHOLA LUDUS VEDECKÁ HRAČKA v decembri 1994. Organizácia bola zaregistrovaná na Ministerstve vnútra Slovenskej republiky 18. januára 1995 pôvodne so sídlom v Bratislave; v súčasnosti v Banskej Bystrici. 
Viaceré aktivity Vedeckej hračky sú rovnaké ako $\mathrm{v}$ podobne zameraných profesionálnych inštitúciách v zahraničí - Koffermuseum v Norimbergu, Deutsches Kinderhilfswerk, e. V. v Berlíne, Pädagogische Aktion/Spielen in der Stadt e. V. v Mníchove, Kinder- und Jugendfreizeitzentrum Wuhlheide v Berlíne atd'. Avšak členovia OZ spolupracujú s učitel'mi - zúčastňujú sa na spoločných podujatiach, podiel'ajú sa na ich príprave a organizácii.

Svojimi aktivitami Vedecká hračka prekračuje hranice Slovenska (8), kde prostredníctvom hračiek prezentuje národnú kultúru Slovenska, ako i možnosti využívania hračiek v edukácii bez rozdielu veku, pohlavia, národnosti či príslušnosti ku kultúre človeka. (9)

Realizácia trvalých ciel'ov OZ:

- vytvárat' priestor pre rozvoj kreativity, záujmových vedecko-technických a výtvarných aktivít vo vol’nom čase najmä detí a mládeže a s tým súvisiace činnosti, smerujúce $\mathrm{k}$ navrhovaniu, vývoju, tvorbe a výrobe vedeckých hračiek a hier,

- etablovat' Centrum hravého poznávania; kým VH tento ciel' nedosiahne, rieši problém inštaláciami stálych interaktívnych výstav. Prvá výstava Hráme sa na vedu je v priestoroch školy skanzenu Slovenského pol'nohospodárskeho múzea $\mathrm{v}$ Nitre. Bola otvorená 25. júna 2002 za účasti vedenia Slovenského pol'nohospodárskeho múzea, zástupcov Agrokomplexu - Výstavníctvo a Univerzity Konštantína Filozofa v Nitre (prof. PhDr. Viera Žbirková, CSc.). Zúčastnili sa i podporovatelia hravého poznávania - Ing. Igor Kollárik, Ing. Michal Malárik, ako aj učitel'ky a deti z nitrianskych základných škôl. Stálu expozíciu navštívi za rok priemerne 5000 osôb. Druhá stála výstava Koleso - vedecká hračka je od októbra 2008 inštalovaná v súkromnom Múzeu kolies v Trenčíne.

Medzinárodná spolupráca:

Vedecká hračka je členom:

- International Federation of Inventors' Associations (IFIA). Členovia OZ vytvárajú pôvodné produkty, chránené alebo prihlásené na priemyselnoprávnu ochranu. Podielaali sa na prezentácii 54 slovenských patentov, úžitkových a priemyselných vzorov $\mathrm{v}$ zahraničí.

- Mouvement International pour le Loisir Scientifique et Technique (MILSET).
Členovia OZ participujú s projektmi na prehliadkach vedecko-technickej tvorivosti detí a mládeže Expo Science Europe a Expo Science International, ktoré spoluorganizuje MILSET.

- International Council for Children's Play (ICCP) - zástupkyňa Slovenska je členka $\mathrm{OZ}$.

Pozn. I ked' Vedecká hračka nie registrovaným členom International Play Association (IPA), spolupracuje $\mathrm{s}$ asociáciou $\mathrm{v}$ rámci realizovaných výskumov a vystúpeniami na vedeckých konferenciách, a iných podujatiach, ktoré organizuje IPA.

Ocenenia:

- Ocenenie predsedníčkou Úradu priemyselného vlastníctva Slovenskej republiky.

Projekt Vedecká hračka prezentovali mladí členovia na bratislavskom Expo Science Europe (ESE) 2002. Odborná porota vyhodnocovala 175 projektov od 301 autorov $\mathrm{v} \quad 8$ sekciách. Vedecká hračka v silnej konkurencii obstála a svoj status čestne obhájila.

- Dar roka 2005 (Slovenská humanitná rada) - Ing. Beata Puobišová, predsedníčka OZ, za aktivity $\mathrm{v}$ oblasti netradičného poznávania, učenia sa a tvorivosti detí a mládeže, za realizáciu a prezentáciu slovenských vedecko-technických projektov detí a mládeže, ako aj za aktivity v občianskom združení Vedecká hračka v poslednom desat'ročí.

- Mestom Banská Bystrica a Centrom dobrovol'níctva $v$ Banskej Bystrici boli dve členky $\mathrm{OZ}$ poctené cenou Srdce na dlani 2007 za venovanie času, schopností a energie $\mathrm{v}$ prospech iných l'udí a komunity. Výsledky:

Aktivity Vedeckej hračky vrátane akvizičnej, organizátorskej, výstavnej, výskumnej a publikačnej činnosti zosumarizoval Korim, V. (10) v konštatovaní, že predstavujú unikátny príspevok k vedeckému skúmaniu danej problematiky, ale svojím spôsobom ide aj o ojedinelú bázu pre aplikovaný výskum voblasti hračiek a hier s prepojením na každodenný život a prácu. Prof. PaedDr. Vojtech Korim, CSc., súčasný dekan Pedagogickej fakulty Univerzity Mateja Bela v Banskej Bystrici, na seminári Hračky v škole 19. marca 2003 v Múzeu SNP v Banskej Bystrici $\mathrm{v}$ podobnom zmysle, hodnotil aj iné aktivity VH. Prehlad 
o výsledkoch činnosti $\mathrm{OZ}$ sú dostupné na www.vedeckahracka.sk.

\section{Vedecká hračka - prostriedok edukácie}

Vedecká hračka je typ hračky, ktorá odráža, zachytáva, približuje, prezentuje alebo demonštruje určitú prírodnú zákonitost' alebo prírodný úkaz. Funkčnost' a princíp vedeckých hračiek je založený na rôznych, prevažne fyzikálnych (mechanických, optických, akustických, elektrických, magnetických) vlastnostiach exponátu a/alebo jeho chemických vlastnostiach. Vedeckú hračku charakterizuje Puobišová, B. (11) ako hračku, ktorá približuje, demonštruje alebo nápadne využíva prírodnú zákonitost' alebo jav a je určená na poznávaciu hru pre deti, mládež, rodiny a iné kolektívy. Jemne odlišným spôsobom ju citovaná autorka vymedzuje v inom zdroji (12) ako nevel'ké mobilné zariadenie, ktoré jednoduchým nenásilným spôsobom približuje alebo využíva nejakú prírodnú zákonitost' alebo jav.

Vedecká hračka spíňa kritériá kvalitnej hračky z pedagogického, psychologického, estetického, zdravotného, hygienického a z d'alších aspektov. Má d'alšie charakteristiky, alebo, ako zvykne uvádzat' Ing. Beata Puobišová, znaky s viac ako „5P“, takže je to hračka: 1. pre všetkých - pohrajú sa s ňou malí i vel'kí, deti i dospelí, 2. prekvapením - ked’že nie je bežnou hračkou, skrýva pre hrajúcich sa určité prekvapenie, 3 . potešenie prináša, 4. poznanie poskytuje, 5 . poučenie obsahuje, 6 . pohodu do duší hrajúcich sa garantuje, 7 . podnety na samostatné učenie sa a na vlastnú tvorbu či výrobu nepatentovaných hračiek zabezpečuje.

\section{Vedecká hračka a neformálna edukácia}

Vedecká hračka realizuje všetky podujatia vo vol'nom čase. Úzko s ním súvisí aj preto, že jej aktivity sú prevažne sebavzdelávacieho a edukačného typu, tzn. že plnia tieto funkcie vol'ného času, ktorý Krystoň, M. (13) charakterizuje ako všetok čas, ktorý človeku zostáva na relatívne slobodné využitie po odpočítaní času potrebného na plnenie si povinností a času potrebného na uspokojovanie biologických a fyziologických potrieb. Medzi znaky vol'ného času patrí možnost' sebavyjadrenia a sebarealizácie na základe potrieb a záujmov, takže pre človeka predstavuje významnú hodnotu, pretože vol'ný čas je priestor na aktivity, ktoré človek chce uskutočnit', ale väčšinou to nemôže v pracovnom či vyučovacom čase. Vol'ný čas je tiež možnost'ou „byt' sám so sebou“ - človek rozmýšl'a a rozjíma o živote, o hodnotách, atd'. Obsahom vol'ného času sú činnosti rôzneho druhu a kvality, ktoré súvisia s možnost'ami ich realizácie. Význam vol'ného času pre človeka spočíva $\mathrm{v}$ regenerácii síl, $\mathrm{v}$ načerpaní energie a vitality $\mathrm{v}$ záujmových činnostiach, odpočinkových a rekreačných činnostiach, spoločensky prospešných činnostiach alebo aj vo sebavzdelávacích a edukačných aktivitách. Uvedené možnosti realizácie vol'ného času sa prelínajú, dopíñajú, podporujú a obohacujú isté aktivity sa ani nedajú rigorózne klasifikovat'.

Pri neformálnej edukácii vychádzame z definície edukácie podla Kosovej, B. Kasáčovej, B. (14), ktoré ju chápu ako organizované a udržiavané sociálne vedenie učiacich sa osôb $\mathrm{k}$ spoločensky hodnotnému rozvíjajúcemu učeniu sa byt', ako aj vedome poznávat', konat', hodnotit', dorozumievat' sa a porozumiet'si, a to podl'a ciel'ového programu na zvládnutie preferovaných obsahov sociokultúry a ciel'ov vlastnej sebarealizácie. Pri porovnaní školskej a neformálnej edukácie badat' síce podobnosti; sú však aj rozdiely nepoužívajú sa rovnaké prostriedky (metódy, formy, učebné pomôcky a i.), rozdielne je i edukačné prostredie. Pre neformálnu edukáciu je príznačné, že:

- je súčastou celoživotného vzdelávania a uskutočňuje sa vo vol'nom čase človeka,

- musí byt' v súlade s platnou legislatívou, podmienky a možnosti musia byt' vopred pripravené v spolupráci regionálnych komunít, vzdelávacích subjektov, médií atd'.,

- musí rešpektovat' spoločenské podmienky a požiadavky praxe, lokálne kultúrne tradície, personálne a ekonomické predpoklady a aj záujmy a potreby potenciálnych frekventantov,

Za úroveň a kvalitu prípravy a organizácie edukačných aktivít vo vol’nom čase zodpovedajú konkrétne vzdelávacie inštitúcie. Jednou z nich je i Vedecká hračka, ktorá interaktívnymi výstavami vytvára prokreatívne edukačné prostredie a organizovaním a vedením prednášok, workshopov a seminárov pre učitel'ov (presnejšie učitel'ky) materských a základných škôl a vychovávatel'ky v školských kluboch detí sa podiel'a aj na ich kontinuálnom vzdelávaní. 


\section{Vedecká hračka - interaktívne výstavy}

Vedecká hračka sa natrvalo zapísala do povedomia verejnosti predovšetkým interaktívnymi výstavami hračiek. Prioritou $\mathrm{OZ}$ je pripravovat' a organizovat' putovné interaktívne výstavy hračiek, hier, hlavolamov a jednoduchých fyzikálnych pokusov. Zrealizovat' takúto výstavu si vyžaduje čas, energiu, kreativitu, ale aj fyzickú námahu a entuziazmus. Avšak pri porovnaní nákladných jednoúčelových centier vedy v zahraničí je predsa len zabezpečit' interaktívnu výstavu hračiek efektívnejšie, jednoduchšie, finančne i personálne menej náročné.

Prvá interaktívna výstava Vedecká hračka prekvapenie, potešenie, poznanie bola od 8 . decembra 1998 v Múzeu SNP v Banskej Bystrici. Jej zameranie vystihuje názov. (15) Počas decénia bolo zrealizovaných 187 interaktívnych výstav vedeckých hračiek v 115 slovenských mestách a obciach v 144 inštitúciách - múzeá, galérie, materské, základné a stredné školy, centrá vol'ného času, knižnice a pod. Tri výstavy boli v zahraničí v Békéscsabe (Mad'arsko) v apríli 2004 Vedecká hračka putuje Európou, v Plzni od októbra 2008 do januára 2009 s titulom Vedecká hračka; Kaleidoskop - vedecká hračka bola do 27. februára 2009 v Kladne.

Jedna kolekcia putovnej výstavy pozostáva z vyše sto exponátov vedeckých hračiek rôznych typov, ktoré pochádzajú $\mathrm{z}$ rôznych štátov, sú vyrobené $z$ rôznych materiálov; ich spoločnou črtou je, že všetky sú efektívnymi a efektnými prostriedkami edukácie. Exponáty sú doplnené textovými manuálmi s príslušnými piktogramami, ktoré približujú prírodovednú podstatu javu alebo zákonitosti zhmotnených v hračke a informujú o:

- tom, ako treba s hračkou manipulovat',

- tom, čo treba pri hre predovšetkým pozorovat' a ako,

- jave alebo zákonitosti spredmetnených v hračke z prírodovedného hl'adiska,

- multikultúrnosti hračky - jej pôvod, kultúrny rozmer a pod.,

- stave priemyselnoprávnej ochrany hračky v SR, príp. iných štátoch. (16)

$\mathrm{Z}$ pozorovania návštevníkov výstav je zrejmý záujem o učenie sa prostredníctvom hry. Robia tak deti, mládež aj dospelí všetkých vekových kategórií vrátane seniorov. Často práve oni odchádzajú z výstavy očarení a dojatí. Mnohí návštevníci sa snažia pochopit' a prijat' princíp fungovania určitej hračky alebo technického princípu spredmetneného $\mathrm{v}$ hračke. Ostatná interaktívna výstava Hodnoty - vedecká hračka bola inštalovaná v Múzeu SNP v Banskej Bystrici od 9. februára 2009 do 3. marca 2009. Ponuka troch interaktívnych výstav VEDECKÁ HRAČKA je dostupná na http://www.muzeum.sk/?obj=putavy\&ix=hnaz.

\section{Vedecká hračka - sút'až}

S ciel'om rozvíjat' tvorivost' svojich členov ako aj širokej verejnosti, OZ každoročne vyhlasuje sút'až $\mathrm{s}$ medzinárodnou účast'ou Vedecká hračka. Je to sút'ažná prehliadka návrhov pôvodnej kvalitnej, funkčnej a estetickej vedeckej a/alebo didaktickej hračky a/alebo hry. V roku 2009 sa uskutočňuje už jej XVII. ročník. Je to jedna $\mathrm{z}$ dôležitých úloh, ktorá zo strany OZ spočíva $\mathrm{v}$ príprave, organizovaní, registrácii a vyhodnocovaní prihlásených námetov a riešení.

\section{Vzdelávanie učitel'ov}

Ďalšie vzdelávanie učitel'ov voblasti ludonómie je jedna $z$ personálne, organizačne i finančne náročných a zároveň aj najzodpovednejších úloh $\mathrm{OZ}$ vo vzt'ahu k edukačnej praxi. Okrem toho, že vo vlastnej réžii (prípadne s podporou sponzorov) vydáva vedecké a odborno-popularizačné publikácie ako zdroje informácií pre učitel'ov, realizuje pre nich aj vzdelávacie podujatia. Ciele a obsah prednášok a seminárov pre učitel'ov sú zamerané na:

- zvýšenie informovanosti učitel'ov o hračkách ich priblížením ako dokumentu kultúry, prostriedku hry a prostriedku výchovy v historických súvislostiach a z pedagogického, psychologického a didaktického aspektu,

- získanie vedomostí, zručností a spôsobilostí učitel'ov na efektívne využívanie hračiek ako didaktických prostriedkov a ich systematické uplatňovanie vo formálnej školskej edukácii,

oboznámenie učitel'ov s vedeckou hračkou - charakteristika, podstata, znaky, tvorba, navrhovanie, získavanie a možnosti jej didaktického využitia,

- motiváciu učitel'ov, aby v edukácii ciel'avedomejšie využívali predovšetkým oblúbené (ale len kvalitné!) hračky detí a vedecké hračky, príp. hračky s didaktickým efektom.

Ilustratívny výpis z evidencie realizovaných podujatí pre učitel'ov: 
- 2. máj 2002 - Topol’čany: Možnosti využitia hračiek ako edukačných médií - prednáška pre učitel'ov základných škôl. (Usporiadatel' - Metodické centrum v Topol'čanoch).

- 4. jún 2003 - Žiar nad Hronom: Hračky v škole - prednáška pre učitel’ov materských, základných a stredných škôl mesta Žiar nad Hronom a blízkeho okolia. (Organizovalo Pohronské osvetové stredisko v Žiari nad Hronom).

- 11. jún 2003 - Stará Lubovňa: Hračky v edukácii - odborno-metodický seminár pre pedagógov materských a základných škôl. (Organizoval Okresný úrad v Starej Lubovni).

- 15. apríl 2004 - Békéscsaba/Mad'arsko: Hračky v škole; Vedecká hračka prednáška a workshop pre učitel'ov. (Organizovala Čabianska organizácia Slovákov).

- 27. máj 2004 - Banská Štiavnica: Hračka edukačný prostriedok - odborný seminár pre pedagógov ZŠ, MŠ a vychovávatel'ov v školských klubov z Banskej Štiavnice a okolitých obcí. (Usporiadatelia Pohronské osvetové stredisko Žiar nad Hronom, Mestský úrad - Odbor školstva v Banskej Štiavnici a riaditel'stvo Osemročného gymnázia A. Kmet’a).

- 17. - 19. marec 2008 - Budmerice: Hračky ako prostriedky edukácie - prednáška a workshop $\mathrm{v}$ rámci prípravy vedúcich pedagogických zamestnancov materských škôl (Usporiadatel' - Metodickopedagogické centrum Bratislava).

V rokoch 2005-2007 organizovalo Metodicko-pedagogické centrum v Banskej Bystrici v spolupráci s Vedeckou hračkou semináre pre učitel'ov Hračky ako prostriedky edukácie. Zúčastnilo sa ich 981 pedagógov z 330 škôl a školských zariadení.

OZ plní d'alšiu náročnú a zodpovednú úlohu súvisiacu s tým, že Ministerstvo školstva Slovenskej republiky akreditovalo 23. júna 2008 podl'a zákona č. 386/1997 Z. z. o d'alšom vzdelávaní pre vzdelávaciu inštitúciu Vedecká hračka, občianske združenie, kurz Hry a hračky ako prostriedky edukácie.

\section{Záver}

Obsahom príspevku je Vedecká hračka, ktorá má trvalé miesto $\mathrm{v}$ živote autorky článku. Najmä dospelí členovia OZ sa snažia vytvárat' možnosti na sebarealizáciu návštevníkov, rozvíjanie ich potencialít a dispozícií hrou, ako jednou z najefektívnejších prostriedkov. Okrem časovej náročnosti a finančných investícií im to prináša radost' a uspokojenie, že v rámci svojich možností prispievajú $\mathrm{k}$ dosiahnutiu ideálu výchovy a $\mathrm{k}$ tomu, aby každý jednotlivec bol dobrý, múdry, aktívny a št’astný človek. O správnom smerovaní Vedeckej hračky svedčí narastajúci záujem o interaktívne výstavy hračiek aj o kontinuálne vzdelávanie učitel'ov. Preto budeme aj nad'alej $v$ tejto ceste pokračovat' a prispievat' kskvalitneniu neformálnej edukácie a života. Vedecká hračka však môže byt' aj inšpiráciou a predobrazom možno i prít’ažlivejších prostriedkov edukácie.

\section{Literatúra:}

(1) BALÁŽOVÁ, E. - PUOBIŠOVÁ, B. Centrum vedy - netradičné edukačné prostredie. In Technológia vzdelávania. Vedecko-pedagogický časopis. Roč. 12, 2004, č. 1, s. 8-11. ISSN 1335-003X.

(2) BALÁŽOVÁ, E. Centrum vedy - prostredie informálneho vzdelávania. In Acta Universitatis Matthaei Belii. Pedagogická fakulta č. 8 . Banská Bystrica : Univerzita Mateja Bela, 2004. s. 16-23. ISBN 80-8083-019-3.

(3) TEPLANOVÁ, K. Katalóg výstavy Schola ludus - Vedecká hračka. Bratislava : SPÚ, 1995. ISBN 80-85756-16-1.

(4) ŽBIRKOVÁ, V. - KRATOCHVÍLOVÁ, E. Výchova vo vol'nom čase a podnety $\mathrm{k}$ činnosti klubov malých debrujárov $\mathrm{v}$ školách a školských zariadeniach. Šal'a : AMD, 1999. ISBN 80-9681-700-0.

(5) KUBÁNIOVÁ, E. Vedecká hračka na ESE 2002. In Technické vzdelanie ako súčast' všeobecného vzdelania. Banská Bystrica : Fakulta prírodných vied UMB, 2002. s. 218223. ISBN 80-8055-734-9.

(6) KORIM, V. Retrospektívny pohl'ad na základné tendencie v problematike hier a hračiek. In BALÁŽOVÁ E. et al. Hračky v škole. Banská Bystrica : Vedecká hračka, 2004. s. 24-28. ISBN 80-968131-37.

(7) ROUČOVÁ, E. Význam a využití technické hračky v preprimární a primární škole. In Hračky - edukačné médiá v Ludotéke. Banská Bystrica : Pedagogická fakulta UMB, 2004, s. 45-56. ISBN 80-8055-561-3.

(8) BALÁŽ, A. Genius Europe očami študenta. In Duševné vlastníctvo. Roč. 8, 2004, č. 2, s. 61-62. ISSN 1335-2881.

(9) PUBIŠOVÁ, B. Vedecká hračka prostriedok výchovy $\mathrm{k}$ tvorivosti. In Hračky 
a hry v 21. storočí. Zborník z medzinárodnej konferencie. Modrý Kameň : SNM - Múzeum bábkarských kultúr a hračiek, 2008. s. 13-18. ISBN 978-808060-224-6.

(10) KORIM, V. Retrospektívny pohl'ad na základné tendencie v problematike hier a hračiek. In BALÁŽOVÁ E. et al. Hračky v škole. Banská Bystrica : Vedecká hračka, 2004, s. 27. ISBN 80-968131-37.

(11) PUBIŠOVÁ, B. Vedecká hračka putuje Európou. Banská Bystrica : Vedecká hračka, 2004. 65 s. ISBN 80-968131-4-5.

(12) PUBIŠOVÁ, B. Vedecká hračka. In BALÁŽOVÁ E. et al. Hračky v škole. Banská Bystrica : Vedecká hračka, 2004. s. 44-66. ISBN 80-968131-37.

(13) KRYSTOŇ, M. Edukácia detí a mládeže vo vol'nom čase. Banská Bystrica : Pedagogická fakulta UMB, 2003. s. 5. ISBN 80-8055-804-3. (14) KOSOVÁ, B. - KASÁČOVÁ, B. Základné pojmy a vzt’ahy v edukácii. Banská
Bystrica : Pedagogická fakulta UMB, 2007. s. 29. ISBN 978-80-8083-525-5.

(15) PUOBIŠOVÁ, B. - BALÁŽOVÁ, E. Scientific Toy. In Play and Education. 23. ICCP World Play Conference, 2004. Krakow : Univerzita Krakow, 2005. CD-ROM. ISBN 8360-356-10-5.

(16) PUOBIŠOVÁ, B. Vedecká hračka. In Hračky - edukačné médiá v ludotéke. Banská Bystrica : Pedagogická fakulta UMB, 2004. s. 36-42. ISBN 80-8055-561-3.

Eva Balážová, PaedDr., PhD.

Katedra elementárnej a predškolskej

pedagogiky

Pedagogická fakulta UMB, Ružová 13

97411 Banská Bystrica

Slovenská republika

Telefón: + 421484464861

E-mail: ebalazova@pdf.umb.sk 